\title{
An Analysis of Workplace Spirituality Debates*
}

\author{
Ahmet Göçen ${ }^{1, *}$, Habib Özğan² \\ ${ }^{1}$ Abdülkadir Karahan Elementary School, Deputy Manager, Turkey \\ ${ }^{2}$ Educational Sciences Department, Gaziantep University, Turkey
}

Copyright $\bigcirc 2018$ by authors, all rights reserved. Authors agree that this article remains permanently open access under the terms of the Creative Commons Attribution License 4.0 International License

\begin{abstract}
While calls for spiritual practices at work increase, the debate to position the concept of Workplace Spirituality (WS) gets thornier. This paper offers a theoretical contribution to the existing debates about spirituality in the workplace in that it addresses the issues of (a) religion, spirituality, and secularity (b) capitalizing the human soul, (c) measuring spirituality, specifically WS (d) indoctrination, (e) the trendy nature of WS. The need for meaning and fulfillment for a greater cause is a long-craved one in organizations. Profit-based organizations have started to consider using spirituality to increase their financial returns by making room for pragmatic spiritual practices, while ontological disputes still continue about whether spirituality could be an asset for inducing profit. Our study starts with a general look at workplace spirituality, continues with criticism and debates rose about "spirituality and a spiritual workplace," and ends with our clarifications regarding these issues.
\end{abstract}

Keywords Workplace Spirituality, Organizations, Criticisms

\section{Introduction}

Western thought has formed a distinctive separation between the world outside of us (the physical realm) and the world inside of us (the spiritual realm), and the intent of this separation, to help people resist dogmatic thought, has actually separated them from what is the best and highest in humanity in many other ways [63]. In recent times, this realization has brought changes in both management and organization. However, the literature still asks the question whether spirituality in the workplace is only a new tool to be used or an important trend to be paid attention [71]. Friedman and Lobel [28] argue that because people spend so much time at work, the quality of the workplace environment can effectively predict the well-being of the workers. This has driven employers to think more about wellness in the workplace, both in terms of physical and spiritual health. Many organizations have begun to pay attention to the concept of workplace spirituality, and more recently, to the concepts of spiritual capital and spiritual intelligence.

The burgeoning research into spirituality workplace began in the 1990s [22, 31, 34]. Although definitions of WS came into prominence in the literature as of the 1990s, Izak [37] takes "the discourse of organizational spirituality" back to the 1930s, into the field of sociology when Max Weber openly mentioned a relationship between a particular individual's religious beliefs and his social and economic activity. Ashmos and Duchon [3] define workplace spirituality as "the recognition that employees have an inner life that nourishes and is nourished by meaningful work that takes place in the context of community. We define it as a shared understanding in the workplace, which allows people to find meaning at work with a sense of serving a superior purpose and integrity among the colleagues. Despite there being not a uniform definition of the term, a framework that denotes workplace spirituality, which has several dimensions, is mainly structured around three structures: a) inner life, b) meaningful and purposeful work, c) a sense of community and connectedness [35], but transcendence -a sensation of utmost joy and connection beyond the self or mystical experience- could be added as the fourth main dimension to this group, as there is a group of results that prove transcendence falls into the dimensions of WS, as shown by Kinjerski and Skrypnek [41], Neck and Milliman [64] and Ashforth and Pratt [4]. Transcendence of self is often discussed in terms of self-actualization of Maslow's needs hierarchy [68]. Maslow [58] went back over his well-known model and placed self-transcendence as another step beyond self-actualization, a move that has attracted researchers such as Fernando [26] and Koltko-Rivera [45] to the field.

Gotsis and Kortezi [33], as Schutte [71] points out, mentions a relationship between spirituality at work and results such as increased commitment to one's goals, productivity and performance at higher levels, reduced absenteeism, increased honesty and trust, increased creativity, increased profits and morale, job satisfaction and intrinsic motivation, and a sense of community with 
one's colleagues. Groups who encourage spirituality in the organizations experience higher financial success and organizational performance [62]. According to Saxena and Saxena [71], workers experiencing workplace spirituality can overcome problems such as depression, nervous problems, alcohol and cigarette use, incompetence, and being overweight. Hence, Long and Mills [55] claimed that spirituality at workplace is a requirement for the development of people and organizations.

Among the emerging debates on spirituality at work, Letourneau [49], in his paper about workplace spirituality, invites people to tell their own perspectives in their approach to spirituality and mentions the well- known scene from the movie "Dead Poets Society," where Mr. Keating recites a poem to his class, ending with: "The powerful play goes on, and you may contribute a verse." Looking at his students, Keating then asks, "What will your verse be?" Thus, our goal is to analyze the debates concerning workplace spirituality and examine different verses.

\section{Methodology}

Our approach in this paper is to examine different point of views regarding workplace spirituality. We will mention several perspectives and criticisms with our interpretations to better present readers with the limits-or open-endedness - of workplace spirituality. We followed the interpretive paradigm methodology to produce a critical review of the literature on spirituality in the workplace. Izak [37 p26] defined this methodology as "the aim of observing on-going processes, to subjectively explore events in order to investigate the interpretations and meanings assigned by social actors." To this end, texts raising the issues of spirituality and secularity, religiosity $[10,22,43]$, WS development programs, spiritual capital within the commodification of human spirituality $[16,51]$, measurement of spirituality [34, 43, 47], indoctrination, and the fad/trendy approach [26, 40] are analyzed and interpreted in light of the related literature and debates, some of which Dent, Higgins and Wharff [21] and Polley, Vora, and Subba Narasimha [69] covered in their studies. As Carson et al. [15] point out; the supporters of interpretive paradigms refrain from using positivist rigid structural frameworks and choose more flexible and personal research structures. This study, by its method, has focused on the most debated topics about WS in the literature and on giving writers' opinions to present a better picture under a personal, flexible course of study.

\section{Findings}

\section{a) Spirituality, Religion, and Secularity}

While religion in the workplace has been approached hesitantly, spirituality appears to be more acceptable in the eyes of modern institutions. Both terms (spirituality and religiosity) are increasingly cited in the titles of professional publications in psychology, but Oman [65, s.23] mentions that while increased citations of religion have been modest, the increased usage of terms related to spirituality has been high, approximately forty-fold.

In regard to the controversial discussions, Badrinarayanan and Madhavaram [5 p423] state that modern psychological approaches distinguish between spirituality and religiosity and cites Terpstra, Rozell and Robinson [73], Westgate (1996), Klenke [42], Kale [38], Marques, Dhiman, and King [57] along with others who tell the differences between spirituality and religion. Hill et al. [34 p619] makes a distinction by stating "spirituality is necessary for religion, but religion is not necessary for spirituality." Of course, different perspectives persist as well. Streib and Klein (2016) urge that spirituality not be established as a scientific concept, either to compete with or to replace "religion." Slater, Hall, and Edwards [72 p17] mention both terms as "religion and its post-modern offspring (spirituality)." Religion could be the best way to approach spirituality by offering a context of existence and giving it a structured meaning in words. This dispute extended itself into the definition of "spiritual capital" as well. While Finke [27], Iannaccone, and Klick [36], as well as Berger and Hefner [7], define spiritual capital with a religious perspective, Zohar and Marshall [76] define the concept as based on a life devoted to service. Liu [53] and Eldred [24] explain the spiritual capital concept within the framework of "attachment to God."

Spirituality in the workplace may cause discussions about the possibility of maintaining a secular workplace [39], since spirituality has historically been rooted in religion [17], and any mention of it may raise secular concerns. Interestingly, spirituality was seen to acquire a sense: secular spirituality, as Chastain [18] and Colledge [19] points out, which focuses on ultimate, meaning giving values in persons [48]. As Duchon and Plowman [22] point out, the lack of attention to spirituality in organizations can, in part, be explained generally by a secular approach to the study of organizational life. The transfer of spiritual knowledge, however, is the oldest discipline in world history. Despite secular calls to abolish religious or spiritual courses, Dreitcer and Liebert [50] say this transfer is now taking place in the classroom environment and in school conference rooms. Spirituality emerged as an academic discipline and has now begun to be taught at universities, as well as academic communities, conferences, new journals, and discussion groups [46]. There is a good amount of evidence which suggests spirituality at work to be thought as a phenomenon which is impacted by teaching [21].

As Koenig [43] points out, "spirituality was once used to describe the deeply religious person, but now it has expanded to include the superficially religious person, the 
religious seeker, and the seeker of calling, meaning, well-being and happiness, and the completely secular person." Moreover, personal spiritual acts sometimes attract similar kinds of people and lead to formations of organized belief systems, making spirituality prone to form an organized system; that is, a minimalistic version of religion through established groups and norms among the people who share the same ideas. According to Dent et al. [21,637], some authors suggest that people and their group will form a doctrine or religion - socially - to account for and lead their spiritual experience to make sense of their spiritual life at work.

Even with the very subjective nature of spirituality, organizations started to offer spirituality training formally within their HRM programs. Some of them were proven to affect organizational outcomes positively [60]. Today, we see organizations that maintain spiritual practicesespecially designed or taken from other belief systems - such as meditation, nature walking, and spiritual text adaptations from holy books or well-known spiritual stories. More interestingly, yoga and meditation are now separated from their religious origin within a secular approach to spirituality. For example, a California appeals court allowed yoga to be continued in elementary schools and ruled that yoga taught in elementary schools is not a gateway to any religion and does not violate religious freedoms [66].

Our understanding is that while workplace spirituality is not based on solely religion or any belief system, it is mainly structured around them in today's context as well. As Gibbons [32] argues spirituality is not much different than religion as religion bears importance for many people. Moreover, it is precisely their religious or other belief systems' principles that shape the people's and organizations' spirituality, in many cases. Yet, most people do make some distinction between the concepts of "religious" and "spiritual." According to Zinnbauer, Pargament, and Scot [75], most people view the terms of spirituality and religiosity as distinct and view themselves as both religious and spiritual. When participants were asked to describe the relationship between religiousness and spirituality, very few respondents $(2.6 \%)$ defined religiousness and spirituality as the same concept, but most of the participants (74\%) in the study identified themselves as both spiritual and religious [74]. Dent, Higgins, and Wharff [21], in their review of 87 scholarly papers, found that 25 of these studies defined spirituality as a religious dimension or tied to religion, 15 papers did not make any reference to religion in definition of spirituality, while 18 papers defined spirituality with both religious and nonreligious perspectives. The remaining 29 studies did not mention the relationship between spirituality and religion.

Akdemir [1] says that the function of true religion is to turn people into their inner world and prevent alienation of the self and nature, thereby realizing the divine inspiration and plan, making love and peace sovereign in the world by pouring eternal possibilities in itself, which is no different than what is supposed in spirituality. Mevlana Jalaluddin Rumi, Yunus Emre, Mother Teresa, and Dalai Lama are perhaps the greatest examples of this view. These spiritual leaders embodied themselves the principles of their own belief systems but came to be known as major spiritual figures in the world and welcomed many people from different backgrounds and religions with their teaching of love:

"Come, come, whoever you are. Wanderer, worshiper, lover of leaving. It doesn't matter. Ours is not a caravan of despair." Mevlana Jalaluddin Rumi

\section{b) Workplace Spirituality and Financial Goals: Capitalizing the Human Soul}

Fenwick and Lange [25] studied human resource development initiatives into areas of spirituality and analyzed examples of spirituality-based human resource programs critically, which show how such programs harbor contradictions and include a fundamentalist zeal, and lead persons towards the need of global marketplace. There is, however, a golden lining. They conclude their paper by exploring "how spirituality might be integrated with work and learning through alternative approaches that are more ethical, ecumenical, ecological, and inclusive (p63)". Lips-Wiersma, Dean, and Fornaciari [51] also point out the somewhat contradictory side of workplace spirituality programs. Similar concerns or ethics-based questions are shared by Dehler and Welsh [20], Polley, Vora, and Subba Narasimha [69], Driver [23], Kamoche [83], LipsWiersma [52], and Berzah and Çakır [11], though spirituality or workplace spirituality practices have been proven to increase performance and have had a positive effect on the organizations or persons $[2,9,12,22,40,60]$. Actually, almost all training programs and models harbor the goal to nurture their participants and turn their skills into profit, without any extra substantial investment.

Most of the existing literature about spirituality is generally concerned to commodify spirituality [16]. What differentiates workplace spirituality from other forms of spirituality is that it is purely subjective and innate and goes against any notion of capital needs met through others with the merits it provides. The paradox is created when companies or firms tend to use spirituality for the sole goals of performance and control, rather than providing what their employees already deserve spiritually. Bell and Taylor [8] explain that workplace spirituality practices can be criticized when they carry a managerial goal for controlling employees. According to Çakır and Berzah [11], some organizations are trying to put into force a spiritual understanding which is based on the capitalist system. Interestingly, WorldCom, Enron, and other corporate scandals around the globe have also added to the growth in the interest of spirituality; the role of business schools in 
turning out CEOs with an overriding drive to increase profit through workplace spirituality has been criticized [26]. Case and Gosling [16, p258] contend strongly against programs that "treat the human as mere resource (bodily, emotional, mental or spiritual) to be deployed within a nexus of economic profit-making activity" Thus, a stronger emphasis on ethics and values in business practices is of crucial importance, as Case and Gosling [16 p265) argue "Knowledge is assessed economically not by its truthvalue, but by its exchange-value. Knowledge is produced to be sold. It becomes subsumed within a flow of capital exchange as part of the consolidation of consumerism within post-industrial societies."

We suggest that organizations, be they for-profit or non-profit, understand workplace spirituality in a natural way by establishing rules of respect for each belief and letting employees realize any kind of spiritual duties they have in the workplace under the leadership of mindful leaders who do not exert or transfer spiritual practices for the reasons of profit or productivity. Capitally masked spirituality may always benefit the company, while an approach to spirituality in a natural form may mostly benefit its workers. For example, Dean, Forniciari, and Safranski [78] in their study questioned how an organization should behave towards the spiritual needs of its members even if these needs are disruptive to the organization or any involved parties. How should an organization decide if 40 Muslim employees want to take a break for their daily prayers altogether? This may leave the organizations undecided between the pure understanding of workplace spirituality and profit concerns, followed by the issue of equality among all members, though these needs can be easily accommodated with a flexible management approach based on pluralistic and spiritual understanding.

According to Polley, Vora, and Subba Narasimha [69 p56], "Workers often volunteer or take lower wages for work in causes they believe in. Organizations come to expect more efforts and commitments from workers without offering equitable rewards. Critics of the capitalist system point to it as a historically important source of discrimination. According to them, the system has led to systematic marginalization and exploitation of the working class." That should be the last place where WS is the victim. Case and Gosling [16] contend that corporations that have endeavored to link spirituality to work rightly deserve a sound critique, since "the work of certain proponents of the positivist workplace spirituality movement represents the latest in a very long line of ideologically infused fantasies about how more productivity can be exacted from employees by aligning their motivations, beliefs, and values with those of the corporation (p268)" Moreover, they argue it is hard to claim that the related studies do not contribute or help, in some ways, to the discourse of capitalist power and control. Interestingly, Lofton [54] too, draws attention to the topic of spirituality and the capitalist adoption of this term by well-known figures by indicating recent episodes and writings of The Oprah Winfrey Show, whose founder advocates methods of meditation, prayer, inner realization to awake one's spirit, and emboldens her followers to find truths for their revolution! "Every product of Winfrey's empire combines spiritual counsel, practical encouragement, and inner awakening with capitalist pragmatism (p599)". Fry [79] cites Patricia Aburdene, the writer of Megatrends 2010 who states that the interest in spirituality in the field of business has become so widespread lately that it now stands as "today's greatest megatrend." Pointing out the rise of spirit in the publishing industry, Robbins [80] claim that books on management and leadership started use "the word of spirit or a similar one" on the front page in increasing manner.

Badrinarayanan and Madhavaram [5] in their study titled "A Framework of the Workplace Spirituality and the Selling Organizations," indicates "sacralization of work" as a consequence of the workplace spirituality dimensions of inner self, meaningful work, and connectedness, claiming "Sales organizations that support workplace spirituality can influence salesperson-related outcomes such as sacralization of work, spiritual well- being, ethical behavior, job commitment, and job satisfaction (p431)." In trying to suggest a solution, Krahnke, Giacalone and Jurkiewicz [47] give future researchers a possible direction, suggesting that researchers explore the ways to integrate spirituality into business to be of service to people's spiritual development rather than find ways to use "spirit" as a tool for the profit in the business.

To combat open and concealed efforts to capitalize the soul, we propose to focus on prioritizing "spiritual capital" in organizations with the core goal not to maximize profit, but rather to foster integrity and trust in the organization. Bayer [6] who examined the book titled Spiritual Capitalism: What the FDNY Taught Wall Street about Money, written by Peter and Monika Ressler, pointed out the need to not allow profit through the suffering of others. $\mathrm{He}$ asserts "Work not only provides an income but also is a service to humankind. The recognition of and acting on this reality is spiritual capitalism, as long as owners focus on integrity, trust, and the wellbeing of their employees as their organization's prime goal (p546)." Any other intention under the term of "spirit" would only lead to false interpretations and place corporate interests first.

\section{c) Measuring Spirituality or WS}

Giacalone and Jurkiewicz [31] identified four main weak points in the discourse of WS: (a) the lack of an accepted definition, (b) inadequate measurement tools, (c) limited theoretical development, and (d) legal and ethical concerns. Dent et al. [21] states that while there are studies that assert workplace spirituality to be measurable, most define several issues with measuring it, though they find it possible to measure spirituality, partially contrary to other 
several articles which assert that the phenomenon cannot be adequately measured with traditional measurement methods. There are a number of problems in measuring spirituality especially in relation to religiosity, e.g. bias, the lack of precision in definitions of various constructs, the issue of illusory spiritual health, ceiling effects, social desirability [72] and limits to researchers' ability to measure constructs like mystical connection, transcendence, and interconnection with non-physical entities [30]. Leaving the problems in WS instrumentalization aside, there is another point raised against WS: how to measure, whom to measure, and on what grounds to measure. Case and Gosling [16] raise a valid point: that any measurement of spirituality on the workplace, whether that of employees or of the corporation as a whole "involve the positioning and subjectification of persons within reductive, instrumental matrices (p261)" Their concern, of course, is a valid one "performative attitude toward the social scientific investigation of workplace spirituality necessitates through measurement and a highly attenuated and narrow conception of 'spirituality,' one that potentially denigrates and impoverishes the meaning that it has for organizational members (p267)" Any such discourse on workplace spirituality should scrutinize the possible or undesired use of human inner resources for capital order.

Wilber [81] takes a different approach. He claims that since spirituality is not of a physical nature, it cannot be sensed or measured empirically. However, Krahnke, Giacalone, and Jurkiewicz [47] try to exemplify their positivist stand in their instrumentalization of the topic by arguing spirituality in the workplace can be a viable tool to improve organizations and their members, which requires a degree of confidence to be attained through scientific measurement. Some of the pioneers in WS, like Duchon and Plowman [22] and Fry [29] pointed out the need to assess "performance" and "spirituality," of course, not to give a hand to corporations to exploit their members' souls, but to help their members realize their inner needs and see the effects on their performance.

The literature still seems to be much undecided about the measurability and credibility of results in the domain of spirituality, as it is on even the definition of WS. It seems a difficult task to measure the transcendent and/or mystical side of people with a fully supported empirical consensus, since spirit, by definition, is beyond the body and the things we see around us. As such, it may require profound, in-depth interviews to catch a glimpse of what it really looks like inside a given human being.

When looked at on the sub-construct levels of WS, e.g. a sense of community, meaningful and purposeful work, connectedness, there does not seem to be much argument about whether certain meaningful life experiences-a person's sense of community or their perceptions of purposeful work--can be measured. Similarly, Dent et al [21 p639] states, "Spirituality may not be measurable, but that there are closely correlated manifestations of spirituality which can."

\section{d) Workplace Spirituality and Indoctrination}

Fry [29] explains that the duty of a spiritual leader is to foster spirituality in the workplace. There are well- known examples of companies whose principles openly express their leader's spiritual grounding [61]. The leader, and sometimes groups within the organization who share the same belief system, do not let other groups with smaller numbers experience their own spirituality. In fact, they may even inhibit them from surfacing, even if a room for spirituality is embedded into the organization's culture. Bruce [13] noted that in a study that a group of people who consider themselves spiritual (with a ratio of 74 percent) were afraid of an imposition of any worldview or belief system that prevailed in the workplace. As a matter of fact, this plight is in contradiction to the practices of workplace spirituality. A welcoming spirituality at work could be greatly affected by the world view of the leader, who may welcome it in theory, but in practice, may try to exert his or her own understanding. Karakas [40] mentions four main problems facing workplace spirituality, as well as solutions to these problems. The first of these problems lies in the danger of proselytism:

a) The proselytism or the imposition of leaders or stronger groups' beliefs \& the accommodation of everyone's spiritual requests.

b) The issues of compatibility \& respect for diversity.

c) The risk of spirituality becoming a fad to manipulate employees \& openness and freedom of expression.

d) The legitimacy problem facing spirituality at work in theory, research, and practice, \& the acknowledgment of employees as whole persons.

The power source may be different for various people: Some may refer to their power source as "the Creator," "the Great," "the Power," "the Spirit," "the Buddha," etc. These sources may be able to meet a person's subjective spiritual needs. In workplace spirituality, therefore, the imperative should be to fulfill employees' spiritual needs of their own free will in the workplace [39]. The spiritual beliefs, if used to exclude others, inhibit respect, harmony and inclusiveness in the workplace [40]. The worse would be to think about secularizing the workplace in a radical sense based on this concern, which will drive the spirit of employees out. This would be akin, in our opinion, to having "plastic flowers with natural color but no fragrance" as persons with fear of expressing their true identity is a stressor and inhabitant to their creativity and workplace wellbeing.

\section{e) Workplace Spirituality and Trends}

The words "spirituality" and "soul" have been showing 
up increasingly in tools aimed at management practitioners and organizational scholars. This, of course, raises flags about whether this is just another management fad [61]. Gibbons [32] claims that human relations, organizational development, total quality management, and quality of work life did not meet organizations' initial expectations and are now out of fashion in the workplace. Gibbons asks whether spirituality in the workplace will face the same fate. Will it, too, fade away? He wonders.

Miller, Hartwick and Breton-Miller [59] mention management information systems (MIS), diversification, and decentralization to be classics in the literature in contrast to TQM, downsizing, reengineering, and Theory $\mathrm{X} /$ Theory $\mathrm{Y}$, depending on the publication counts of administrative fads and classics in the years between 1985 and 2001. They concluded that life cycles of fads and classics are quite different. Fads experience a cycle of quick adoption and then a quick rejection of the theory. Classics prevail.

While there has been concern that workplace, spirituality could fade away, Marie [56] asserts several studies in the literature suggest otherwise as workplace spirituality has roots in earlier management theories and is an inevitable part of management. The possibility of WS being another fad cannot be related to the essence of spirituality in one's working life in its pure form, but rather to its capitalization-oriented applications in profit- based institutions. It is a justifiable concern for Karakas [40], upon examination of workplace spirituality studies, as seen in popular books, practices and trainings related to spirituality. The main problem is caused with the misuse of workplace spirituality as a management or a marketing tool, which causes "a loss of authenticity". Indeed, Fernando [26] claimed that using spirituality in the workplace as a means to accomplish economic goals leads to a faddish approach.

All in all, despite the claims of the possibility of its becoming a management fad (mainly due to its being a management or a marketing tool), there is no established literature that proves that WS is actually a management fad. Spirituality at work may be in the early stages of its life cycle and may become more widely adopted after additional evidence is presented. Actually, most of the studies examined imply that spirituality in its essence is and will be an undeniable part of organizations. Similarly, Burack [14] points out "spirituality" as an indispensable theme among the vital changes in the workplace. Vasconcelos [77 p607] contends, "The spiritual paradigm has gradually evolved from an apparent management fad to a theme worthy of respect, given that it is attracting increasingly intellectual curiosity and personal searches to understand this phenomenon." The interest into spirituality as a natural need in people is far from being fad. The problem lies in how the practitioners will use and shape it, either in its natural form - as a right of human beings in the workplace - or a capitalization-oriented form geared towards quality, performance, and profit, following in the footsteps of TQM.

\section{Conclusions}

Dent et al. [21] examined the literature about workplace spirituality and found seven themes including "tied to religion, epiphany, teachable, individual development, measurable, productive/profitable, nature of the phenomenon," and Polley, Vora and Subba Narasimha [69 p50] specified six themes to be critically attended for successful management of spirituality at work: (a) net economic cost of implementation, (b) potential for worker exploitation, (c) replacing or substituting the community's function or role in spirituality, (d) inappropriate practice of spirituality in the workplace, (e) potential for competitive disadvantage, and (f) increased groupthink, some of which are directly related to debates in our study. Hundreds of papers have been published about WS, subsequent to the studies of Dent et al. [21] and Polley et al. [69], including all critical points and debates included in our study: "Spirituality, Religion, and Secularity," "Capitalizing the Human Soul," "Measuring Spirituality," "Indoctrination," "Fad or Trendy Nature," all of which were discussed separately or together by the authors of Duchon and Plowman [22], Koeing [43], Benefiel, Fry and Geigle [10], Lips-Wiersma, Dean, Fornaciari [51], Case and Gosling [16], Krahnke, Giacalone and Jurkiewicz [47], Hill. et al. [34]; Polley, Vora and Subba Narasimha [69]; Karakas [40], and Fernando [26]. We presented our opinions and stated our understanding about the nature of WS and these debates in line with the literature covering the last three decades.

The workplace spirituality as a concept can be thought at the organizational and individual levels [44]. Our perspective in defining workplace spirituality is an understanding that allows people to find meaning at work, creates a feeling of serving a purpose beyond the self with the acceptance of the inner world in the organization, and a feeling of being connected and transcendent. Workplace spirituality should be considered as an approach that explains the sincere behaviors and attitudes of group members for a meaningful purpose with altruistic feelings and a sense of belonging that creates transcendence and unity within the diversity, devoid of any financial returns. Critical papers about workplace spirituality do not assert that workplace spirituality is inappropriate and not fit for personal realization or organizational development, but instead focus on the ways in which spirituality can be abused, especially for managerial control [23]. With the entrance of WS into scientific studies, WS has proved itself to be on the way to become one of the most important topics in organizational management. Similarly, Rego and D'Oliveira [82] mention that every theory of organization is, in fact, a theory of organizational spirituality. That being said, spirituality in the workplace has attracted a great 
interest from many disciplines in their respective literature, since some mechanical management mentalities, sometimes under the mask of radical secularism, forced people to leave their thoughts and inner world outside the doors of the workplace. For us, WS is one of the most important milestones in restructuring existing management practices to welcome human body/capital/spirit into the workplace. Therefore, it requires a well- structured approach to treat workplace spirituality in today's context. Clearly, a desired system of spirituality, structured around the common good of all members with a non-discriminative spiritual leadership, is what people want in their own organizations for their spiritual growth or wellbeing. While doing so, the religious and spiritual needs of people are to be considered, not in terms of the pragmatic needs of organizations, but rather in terms of the pragmatic needs of people for their own self-actualization and transcendence. If understood as it is, it would be genuinely beneficial for employees to work in an environment with the characteristics ascribed to spiritual organizations [69].

Hill et al. [34] mention the transition from "advocacy to a science" in the study of workplace spirituality. The attempts to measure spirituality and workplace-related outcomes are desirable in terms of the positivist paradigm, since it is natural for policymakers, leaders, etc., to know what they need to invest in or embed in their organization. Leading organizations are likely to remain disinterested in forming spiritual environments at work if a demonstrable and clear (though not necessarily financial) type of outcome associated with WS is not proved [34]. However, the interpretive paradigm must not be ignored on the grounds of positivist concerns. Actually, it should be given the utmost consideration as it can enlighten many points along with scientific knowledge. Aristotle once said, "Intuition, together with scientific knowledge, comprises true wisdom" [47 p399].

Using WS as an indoctrination tool will not produce the intended atmosphere that spirituality at work foresees. The imposition of leaders or the beliefs of the larger groups in the organization makes WS no different than some secular movements that drove religious symbols out of organizations in recent decades, the only difference being the allowance of one specific belief system and its practices. The opposite, the exclusion of spirituality for the fears of imposition or any religion manifestation at work, can produce undesirable results as well. Palmer [67] points to possible harm, especially in decision-making, when spirituality is not in place and mentions the concept of "functional atheism," the idea that ultimate responsibility for everything rests with me leads to managers imposing their will on others, leading to an increased stress and burnout potential. In any case, imposing a specific spiritual understanding or personal desire, followed by the desire to capitalize the human soul, may lead the organization into a fading process. The topic of spirituality, as an inevitable part of human need, psychology, social interaction, and well-being at the workplace, will continue to exist as long as its interpretation is done in its pure form.

Due to secular concerns, the tendency in public education and in many private arenas has been building a wall between religion and the state or organization, which has led thoughts and feelings about spiritual matters to be a never-mentioned topic in most organizations [61]. Today, faced more with the case of welcoming spirituality in the workplace without concern and prejudice, organizations should approach WS with an understanding that it is not to be built on fears of secularism or, conversely, the misused, proselytized side of belief systems. Further studies need to focus on examining purer and to-the-point applicable forms of spirituality in organizations for inner growth, psychological well-being and integrity, and amalgamation of members into core human principles. These actually can be seen on the road maps of many organizations. The problem starts in the application of these principles, when all sorts of tensions inherent in the application processsome of which were indicated above-start to surface. How to embed WS in true wisdom needs to be one of the most researched topics in the next studies in the field of organizational management.

\section{REFERENCES}

[1] Akdemir, S. Din ve Laiklik [Religion and Secularism], 2000; İstanbul: Form Yayıncılık

[2] Arnold JL. Spirituality in the workplace and its impact on organizational performance (Doctoral dissertation, The College of St. Scholastica). 2010. Retrieved from https://search.proquest.com/docview/757374883?accountid $=15958$

[3] Ashmos DP, Duchon D. Spirituality at work: A conceptualization and measure. Journal of management inquiry. 2000 Jun; 9(2):134-45.

[4] Ashforth BE, Pratt MG. Institutionalized spirituality. Handbook of workplace spirituality and organizational performance. 2003:93-107.

[5] Badrinarayanan V, Madhavaram S. Workplace spirituality and the selling organization: A conceptual framework and research propositions. Journal of Personal Selling \& Sales Management. 2008 Sep 1; 28(4):421-34.

[6] Bayer R. Spiritual Capitalism: What the FDNY Taught Wall Street About Money. Journal of Markets \& Morality. 2005 Sep 22; 8(2):545-7.

[7] Berger PL, Hefner RW. Spiritual capital in comparative perspective. In Spiritual Capital Planning Meeting 2003 Oct (pp. 10-11).

http://www.metanexus.net/archive/spiritualcapitalresearchp rogram/pdf/Berger.pdf [accessed January 26, 2017]

[8] Bell E, Taylor S. The elevation of work: Pastoral power and the new age work ethic. Organization. 2003 May; 
10(2):329-49.

[9] Benefiel M. The second half of the journey: Spiritual leadership for organizational transformation. The leadership quarterly. 2005 Oct 1; 16(5):723-47.

[10] Benefiel M, Fry LW, Geigle D. Spirituality and religion in the workplace: History, theory, and research. Psychology of Religion and Spirituality. 2014 Aug; 6(3):175.

[11] Berzah MÇ, Çakır M. İş Hayatında Maneviyat Yaklaşımı Ne Vaadediyor? Journal of Administrative Sciences/ Yonetim Bilimleri Dergisi. 2015 Jun 1; 13(26).

[12] Biberman J, Whitty MD. Work and spirit: A reader of new spiritual paradigms for organizations. Scranton, PA: University of Scranton. 2000.

[13] Bruce WM. Public administrator attitudes about spirituality: An exploratory study. The American Review of Public Administration. 2000 Dec; 30(4):460-72.

[14] Burack EH. Spirituality in the workplace. Journal of organizational change management. 1999 Aug 1; 12(4):280-92.

[15] Carson D, Gilmore A, Perry C, Gronhaug K. Qualitative marketing research. Sage; 2001 Feb 1.

[16] Case P, Gosling J. The spiritual organization: critical reflections on the instrumentality of workplace spirituality. Journal of Management, spirituality and Religion. 2010 Dec $1 ; 7(4): 257-82$.

[17] Cavanagh GF. Spirituality for managers: Context and critique. Journal of organizational change management. 1999 Jun $1 ; 12(3): 186-99$.

[18] Chastain D. Gifts without Givers: Secular Spirituality and Metaphorical Cognition. Sophia. 2017 Dec 1; 56(4):631-47.

[19] Colledge RJ. Secular spirituality and the hermeneutics of ontological gratitude. Sophia. 2013 Apr 1; 52(1):27-43.

[20] Dehler GE, Welsh MA. Spirituality and organizational transformation: Implications for the new management paradigm. Journal of managerial psychology. 1994 Nov 1; $9(6): 17-26$

[21] Dent EB, Higgins ME, Wharff DM. Spirituality and leadership: An empirical review of definitions, distinctions, and embedded assumptions. The leadership quarterly. 2005 Oct $1 ; 16(5): 625-53$.

[22] Duchon D, Plowman DA. Nurturing the spirit at work: Impact on work unit performance. The leadership quarterly. 2005 Oct 1; 16(5):807-33.

[23] Driver M. New and useless: A psychoanalytic perspective on organizational creativity. Journal of Management Inquiry. 2008 Sep; 17(3):187-97.

[24] Eldred KA. God is at Work. Regal Books; 2005.

[25] Fenwick T, Lange E. Spirituality in the workplace: The new frontier of HRD. Canadian Journal for the Study of Adult Education. 1998 May 1; 12(1):63-87.

[26] Fernando M. Workplace spirituality: Another management fad? Faculty of Commerce - Papers. 2005.

[27] Finke R. Spiritual capital: Definitions, applications, and new frontiers. Retrieved April. 2003 Oct 10; 24: 2005

[28] Friedman SD, Lobel S. The happy workaholic: A role model for employees. The Academy of Management Executive. 2003 Aug 1; 17(3):87-98.

[29] Fry LW. Toward a theory of spiritual leadership. The leadership quarterly. 2003 Dec 1; 14(6):693-727.

[30] Geigle D. Workplace spirituality empirical research: A literature review. Business and Management Review. 2012; 2(10):14-27.

[31] Giacalone RA, Jurkiewicz CL. Toward a science of workplace spirituality. Handbook of workplace spirituality and organizational performance. 2003:3-28.

[32] Gibbons P. Spirituality at work: Definitions, measures, assumptions, and validity claims. Work and Spirit: A Reader of New Spiritual Paradigms for Organizations, University of Scranton Press, Scranton, PA. 2000 Aug 4:111-31.

[33] Gotsis G, Kortezi Z. Philosophical foundations of workplace spirituality: A critical approach. Journal of business ethics. 2008 Apr 1; 78(4):575-600.

[34] Hill PC, Jurkiewicz CL, Giacalone RA, Fry LW. From concept to science: Continuing steps in workplace spirituality research. 2013:617-631

[35] Houghton JD, Neck CP, Krishnakumar S. The what, why, and how of spirituality in the workplace revisited: A 14-year update and extension. Journal of Management, Spirituality \& Religion. 2016 Jul 2; 13(3):177-205.

[36] Iannaccone LR, Klick J. Spiritual capital: An introduction and literature review. 2003 Oct 9; Retrieved from http://www.metanexus.net/archive/spiritualcapitalresearchp rogram/pdf/review.pdf

[37] Izak M. Spiritual episteme: sensemaking in the framework of organizational spirituality. Journal of organizational change management. 2012 Feb 10; 25(1):24-47.

[38] Kale SH. Spirituality, religion, and globalization. Journal of Macromarketing. 2004 Dec; 24(2):92-107.

[39] Baloğlu N, Karadağ E. A theoretical analysis about spiritual leadership. Kuram ve Uygulamada Eğitim Yönetimi. 2009: 58; $165-190$.

[40] Karakas F. Spirituality and performance in organizations: A literature review. Journal of business ethics. 2010 Jun 1; 94(1):89-106.

[41] Kinjerski VM, Skrypnek BJ. Defining spirit at work: Finding common ground. Journal of organizational change management. 2004 Feb 1; 17(1):26-42.

[42] Klenke K. The "S" factor in leadership education, practice, and research. Journal of Education for Business. 2003 Sep 1; 79(1):56-60.

[43] Koenig HG. Concerns about measuring "spirituality" in research. The Journal of nervous and mental disease. 2008 May 1; 196(5):349-55.

[44] Kolodinsky RW, Giacalone RA, Jurkiewicz CL. Workplace values and outcomes: Exploring personal, organizational, and interactive workplace spirituality. Journal of business ethics. 2008 Aug 1; 81(2):465-80. 
[45] Koltko-Rivera ME. Rediscovering the later version of Maslow's hierarchy of needs: Self-transcendence and opportunities for theory, research, and unification. Review of general psychology. 2006 Dec; 10(4):302.

[46] Kourie C. The "turn” to spirituality. Acta Theologica. 2007; 27(2):19-40

[47] Krahnke K, Giacalone RA, Jurkiewicz CL. Point-counterpoint: Measuring workplace spirituality. Journal of organizational change management. 2003 Aug 1; 16(4):396-405.

[48] Kurtz E, White WL. Recovery spirituality. Religions. 2015 Jan 27; 6(1):58-81.

[49] Letourneau J. Mission Integration and Workplace Spirituality. Health progress (Saint Louis, Mo.). 2016; 97(2):30-2.

[50] Liebert E, Dreitcer AD. The spirituality of the teacher. The Way Supplement. 1995; 84:40.

[51] Lips-Wiersma M, Lund Dean K, Fornaciari CJ. Theorizing the dark side of the workplace spirituality movement. Journal of management inquiry. 2009 Dec; 18(4):288-300.

[52] Lips-Wiersma M. Furthering Management and Spirituality Education through the Use of Paradox. Journal of Management Education. 2004 Feb; 28(1):119-33.

[53] Liu, A. 4Capital and Performance. 2007. Available at http://www.researchmethods.org/be4capital.htm (accessed on 16.01.2017)

[54] Lofton K. Practicing Oprah; or, the prescriptive compulsion of a spiritual capitalism. The journal of popular culture. 2006 Aug 1; 39(4):599-621.

[55] Long BS, Helms Mills J. Workplace spirituality, contested meaning, and the culture of organization: A critical sensemaking account. Journal of Organizational Change Management. 2010 May 25; 23(3):325-41.

[56] Marie B. Workplace Spirituality. Culture \& Religion Review Journal, 2011(2): 52-62.

[57] Marques J, Dhiman S, King R. Spirituality in the workplace: Developing an integral model and a comprehensive definition. Journal of American Academy of Business. 2005 Sep; 7(1):81-91.

[58] Maslow AH. The farther reaches of human nature. The Journal of Transpersonal Psychology. 1969 Apr 1; 1(1):1.

[59] Miller D, Hartwick J, Le Breton-Miller I. How to detect a management fad - and distinguish it from a classic. Business Horizons. 2004 Jul 1; 47(4):7-16.

[60] Milliman J, Ferguson J, Trickett D, Condemi B. Spirit and community at Southwest Airlines: An investigation of a spiritual values-based model. Journal of organizational change management. 1999 Jun 1; 12(3):221-33.

[61] Mirvis PH. Crossroads - "soul work" in organizations. Organization Science. 1997 Apr; 8(2):192-206.

[62] Mitroff II, Denton EA. A study of spirituality in the workplace. MIT Sloan Management Review. 1999 Jul 1; $40(4): 83$

[63] Neal J, Biberman J. Introduction: The leading edge in research on spirituality and organizations. Journal of organizational change management. 2003 Aug 1; $16(4): 363-6$

[64] Neck CP, Milliman JF. Thought self-leadership: Finding spiritual fulfillment in organizational life. Journal of managerial psychology. 1994 Nov 1; 9(6):9-16.

[65] Oman D. Defining religion and spirituality. Handbook of the psychology of religion and spirituality. 2013 May 21; 2: $23-47$.

[66] Palazzolo, J. California Appeals Court Rules Yoga Doesn't Violate Religious Freedom. The Wall Street Journal. 2015 April 5; Retrieved from https://www.wsj.com/articles/california-appeals-court-rules -yoga-doesnt-violate-religious-freedom-1428261496

[67] Palmer PJ. Let your life speak: Listening for the voice of vocation. John Wiley \& Sons; 1999 Sep 10.

[68] Pardasani R, R. Sharma R, Bindlish P. Facilitating workplace spirituality: lessons from Indian spiritual traditions. Journal of Management Development. 2014 Sep 2; 33(8/9):847-59

[69] Polley D, Vora J, Subba Narasimha PN. Paying the devil his due: Limits and liabilities of workplace spirituality. International journal of organizational analysis. 2005 Jan 1; $13(1): 50-62$

[70] Saxena A., and Saxena A. Workplace Spirituality: A Basic Pillar for Modern Management, International Journal of Management Research and Review, 2011; 1(1) Available from

http://ijmrr.com/admin/upload data/journal 2 article Abh ay.pdf

[71] Schutte PJ. Workplace spirituality: A tool or a trend?. HTS Theological Studies. 2016; 72(4):1-5.

[72] Slater W, Hall TW, Edwards KJ. Measuring religion and spirituality: Where are we and where are we going? Journal of psychology and theology. 2001 Apr 1; 29(1):4

[73] Terpstra DE, Rozell EJ, Robinson RK. The influence of personality and demographic variables on ethical decisions related to insider trading. The Journal of Psychology. 1993 Jul $1 ; 127(4): 375-89$

[74] Zinnbauer BJ, Pargament KI, Cole B, Rye MS, Butter EM, Belavich TG, Hipp KM, Scott AB, Kadar JL. Religion and spirituality: Unfuzzying the fuzzy. Journal for the scientific study of religion. 1997 Dec 1:549-64.

[75] Zinnbauer BJ, Pargament KI, Scott AB. The emerging meanings of religiousness and spirituality: Problems and prospects. Journal of personality. 1999 Dec 1; 67(6):889-919.

[76] Zohar D. Exploring spiritual capital: An interview with Danah Zohar. Spirituality in Higher Education Newsletter. 2010;5(5)

[77] Vasconcelos AF. Spiritual development in organizations: A religious-based approach. Journal of business ethics. 2010 Jun 1; 93(4):607-22.

[78] Dean KL, Fornaciari C, Safranski SR. The ethics of spiritual inclusion. In Spirituality in Business 2008 (pp. 188-202). Palgrave Macmillan, New York. 
[79] Fry LW. Spiritual leadership: State-of-the-art and future directions for theory, research, and practice. In Spirituality in business 2008 (pp. 106-124). Palgrave Macmillan, New York.

[80] Robbins, S. Organizational behavior. Upper Saddle River: Prentice Hall. 2003

[81] Wilber, K. A Brief History of Everything, Shambhala Publications. 2000

*This paper is based on the discussion of related literature in Ahmet Göçen's PhD thesis titled "An Experimental Implementation to Develop Workplace Spirituality in Educational Organizations"
[82] Rego A, D'Oliveira T. Management ideologies and organizational spirituality: a typology. 2004. FEUNL Working Paper No. 452. http://dx.doi.org/10.2139/ssrn.882438

[83] Kamoche, K.. Organizational spiritualism: Toward a critical analysis. 2003; Paper presented at the Academy of Management, Seattle, WA. 